\title{
Phytochemical analysis, antimicrobial and antioxidant activities of Euphorbia golondrina L.C. Wheeler (Euphorbiaceae Juss.): an unexplored medicinal herb reported from Cameroon
}

\author{
Lawrence Monah Ndam ${ }^{1 *}$, Afui Mathias Mih'1, Aaron Suh Tening ${ }^{2}$, Augustina Genla Nwana Fongod', \\ Nkegua Anna Temenu ${ }^{3}$ and Yoshiharu Fujii ${ }^{4}$
}

*Correspondence:
nlmonah@yahoo.com
${ }^{1}$ Department of Botany
and Plant Physiology,
University of Buea, P.O.
Box 63, Fako, South West
Region, Cameroon
Full list of author information
is available at the end of the
article

*Correspondence:

rmonah@yahoo.com

and Plant Physiology,

University of Buea, P.O.

Region, Cameroon

is available at the end of the article

\begin{abstract}
This study aimed at determining the phytochemical constituents of Euphorbia golondrina L.C. Wheeler, an alien invasive medicinal herb that is used for the treatment of gastroenteritis related ailments, diabetes, conjunctivitis, gastritis, enterocolitis, tonsillitis, vaginitis, hemorrhoids, prostatism, warts and painful swellings by the Mundani people of the mount Bambouto Caldera in SouthWestern Cameroon, and to evaluate its in vitro antimicrobial and antioxidant activities. Susceptibility testing by agar well diffusion assay revealed good antibacterial activity with inhibition zone diameter of $20 \pm 1.1 \mathrm{~mm}$ against Bacillus cereus followed by Staphylococcus aureus with inhibition zone diameter of $17 \pm 1.6 \mathrm{~mm}$ which was significantly lower $(P<0.05)$ than the positive control (amoxicillin). None of the fungi was inhibited by the acetone extract of $E$. golondrina except Candida albicans wherein the zone of inhibition was not significantly different from that of the positive control (Amphotericin B). The ABTS scavenging activity of E. golondrina was higher than that of gallic acid and BHT at concentrations greater than 0.1 and $0.2 \mathrm{mg} / \mathrm{mL}$ respectively while at all concentrations, nitric oxide scavenging activity was higher than those of both rutin and vitamin C. GC-MS profile of E. golondrina steam distilled volatiles revealed that the plant has potent phytoconstituent classes such as sesquiterpenes, monoterpenes, alkaloids, phenolics and aromatic hydrocarbons. Among the 30 compounds identified, caryophyllene oxide (14.16\%), camphor (9.41\%) and phytol (5.75\%) were the major compounds. Further structural characterisation based on ${ }^{1} \mathrm{H}$ and ${ }^{13} \mathrm{C}$ NMR is required to demonstrate structural integrity including correct stereochemistry. The current study partially justifies the ethnomedicinal uses of E. golondrina in Cameroon.
\end{abstract}

Keywords: Euphorbia golondrina, Antioxidant activity, Antimicrobial activity, Phytochemicals, GC-MS

\section{Background}

Increasing trends of microbial resistance to antibiotics and various chronic and degenerative pathologies of humans caused by reactive oxygen species(ROS) have triggered the

() 2016 Ndam et al. This article is distributed under the terms of the Creative Commons Attribution 4.0 International License (http:// creativecommons.org/licenses/by/4.0/), which permits unrestricted use, distribution, and reproduction in any medium, provided you give appropriate credit to the original author(s) and the source, provide a link to the Creative Commons license, and indicate if changes were made. 
search for bioactive compounds from plants with alternative mechanisms of action to counteract pathogenic microbes and natural antioxidants capable of protecting the body against oxidative stress and free radical-induced damage (Lu et al. 2007; Mbwambo et al. 2007; N'guessan et al. 2007; Newman and Cragg 2007; Duracková 2010; Reuter et al. 2010; Davies and Davies 2010; Buffet-Bataillon et al. 2012). The plant kingdom habours enormous amounts of therapeutic agents that have diverse applications in the pharmaceutical, nutraceutical and agrochemical industries. The active principles responsible for the therapeutic effects of medicinal plants are phytochemicals, usually secondary metabolites, including but not limited to alkaloids, steroids, flavonoids, terpenoids and tannins (NONITA et al. 2010). Of the reported 500000 species of higher plants, only about 6 and $15 \%$ have been evaluated for biological activity and phytochemical analysis respectively (Fabricant and Farnsworth 2010; Verpoorte 2000). Over $50 \%$ of drugs are of plant origin (Balandrin et al. 1993). The tedious process of plant-based discovery is often based on knowledge of ethnopharmacopoeia of the plant. Such medicinal plants are screened in vitro for bioactivity using several techniques. Further identification of the lead compounds is based on the diversity of secondary metabolites or phytochemicals produced by the plants.

Euphorbia golondrina L.C. Wheeler (Syn. Chamaesyce golondrina (L.C. Wheeler) Shinners) belongs to the Euphorbiaceae family and the subgenus Chamaesyce. It is an herbaceous weedy plant found in the USA, Mexico and Cameroon (Ndam et al. 2015a). In the African ethnopharmacopoeia, it is known to treat gastroenteritis related ailments (Ndam et al. 2015a). An infusion of the roots is used in the management of diabetes while a decoction of the leaves mixed with Senna alata is exploited in the treatment of conjunctivitis, gastritis, enterocolitis, tonsillitis, vaginitis, hemorrhoids, prostatism and snake poison (Aleksandroff 2011; Rodriguez, 2013). The white latex from the stem is employed as an ointment in the treatment of warts and painful swellings by the Mundani people of the mount Bambouto Caldera, SouthWestern Cameroon (Ndam et al. 2015b). There is no information on the bioactivity and the phytochemical composition of this plant. Therefore in this study, the antimicrobial activity of E. golondrina against a panel of standardized pathogenic fungi and bacteria and the antioxidant properties of the acetone crude extract of the plant were elucidated. The phytochemical screening of the plant was also done to identify the secondary metabolites occurring in it.

\section{Methods}

\section{Plant and preparation of crude extract}

The E. golondrina earlier identified (Ndam et al. 2014, 2015a) was obtained in 2015 from the mount Bambouto caldera, SouthWestern Cameroon. The fresh leaves of the plant were cut, surface sterilised with $70 \%$ alcohol and rinsed with sterile distilled water. The leaves were air-dried at room temperature for one month, mechanically ground to a fine powder by an electrical blender and further air-dried for 3 days. One hundred grams $(100 \mathrm{~g})$ of the powder was macerated in $1000 \mathrm{~mL}$ of acetone for $48 \mathrm{~h}$ three times under room temperature $\left(22-25^{\circ} \mathrm{C}\right)$. After filtering the resultant solution through a Whatman No. 1 grade filter paper, the filtrate was then concentrated to dryness under pressure at a maximum of $40^{\circ} \mathrm{C}$ using a rotary evaporator (BUCHI Rotavapor R-200, Switzerland). The concentrate was recovered with a minimum volume of dichloromethane and kept 
open at room temperature until all the residual solvent had evaporated. The dried crude extract was weighed, and kept in a bottle sealed with parafilm and stored at $4{ }^{\circ} \mathrm{C}$ until used. An aliquot of the extract was resuspended in acetone to yield a $100 \mathrm{mg} / \mathrm{mL}$ stock solution (Koduru et al. 2006). The yield (\%,w/w) of the dried extract was calculated as: Yield $(\%)=(\mathrm{W} 1 \times 100) / \mathrm{W} 2$, where W1 is the weight of the extract after lyophilization of solvent, and W2 is the weight of the plant powder.

\section{Microorganisms and antimicrobial susceptibility assays}

The microbes used in this study were three Gram-positive bacteria: Staphylococcus aureus, Enterococcus faecalis and B. cereus and one Gram-negative bacterium (Escherichia coli). Antifungal assays were evaluated using Candida albicans, Penicillium chrysogenum, Aspergillus fumigatus, and Aspergillus niger. These microbes were chosen primarily on the basis of their importance as pathogens of humans. Pure cultures of all experimental bacteria and fungi were American Type Culture Collection (ATCC), obtained from Total Laboratory, South Africa.

Nutrient agar and Sabouraud dextrose agar (SDA) media were prepared and poured into sterilised disposable petri dishes under aseptic conditions according to the recommendations of the manufacturer. The plates were labeled and inoculated with $100 \mu \mathrm{L}$ of 0.5 Mcfarland solutions of the respective organisms, and loaded with extract of $E$. golondrina $(50 \mathrm{mg} / \mathrm{mL})$ into $6 \mathrm{~mm}$ wells. Amoxicillin and Amphotericin B $(25-50 \mu \mathrm{g} /$ well) were used as positive controls for bacteria and fungi respectively. Each test was replicated three times. After proper incubation period at $37^{\circ} \mathrm{C}$, zones of inhibition were recorded in millimeters. The microdilution method was employed to determine the minimum inhibitory concentration (MIC) of the plant extracts using 96 well microtitre plates as previously described (Otang et al. 2012). The smallest concentration of the plant extract that was able to kill the microorganisms was considered as the minimum inhibitory concentration (MIC).

\section{Antioxidant assays}

\section{Assay of DPPH scavenging activity}

The DPPH (1,1-diphenyl-2-picrylhydrazyl) radical-scavenging activity of the test extracts was examined as previously described (Ebrahimzadeh et al. 2010). Different concentrations $(0.025-0.5 \mu \mathrm{g} / \mathrm{mL})$ of each extract were added, at an equal volume, to methanolic solution of DPPH $(100 \mu \mathrm{M})$. The mixture was kept in the dark for $30 \mathrm{~min}$. Vitamin C and Rutin were used as standard controls and three replications were made. After $30 \mathrm{~min}$, the absorbance (A) was measured at $518 \mathrm{~nm}$ and converted into the percentage antioxidant activity using the following equation: \% Scavenged $[\mathrm{DPPH}]=[(\mathrm{Ao}-\mathrm{A} 1) / \mathrm{Ao}] \times 100$, where Ao was the absorbance of the control and A1 was the absorbance of extract and standard.

\section{Assay of nitric oxide scavenging activity}

This assay was done according to the procedure of Ebrahimzadeh et al. (2010). Two $\mathrm{mL}$ of $10 \mathrm{mM}$ sodium nitroprusside in $0.5 \mathrm{mM}$ phosphate-buffered saline ( $\mathrm{pH}$ 7.4) was mixed with different concentrations of the acetone extract of E. golondrina dissolved in water and incubated at $25{ }^{\circ} \mathrm{C}$ for $2.5 \mathrm{~h}$. After the incubation period, $0.5 \mathrm{~mL}$ of Griess 
reagent was added and the absorbance was read at $540 \mathrm{~nm}$. The Inhibition of nitric oxide radical generation was measured by comparing the absorbance value of the controls (Vitamin $\mathrm{C}$ and Rutin) with that of the test solution.

\section{Reducing power assay}

Different concentrations $(0.025-0.05 \mu \mathrm{g} / \mathrm{mL})$ of the acetone extract of the plant in distilled water were mixed with $2.5 \mathrm{~mL}$ of $0.2 \mathrm{M}$ phosphate buffer $(\mathrm{pH} \mathrm{6.6)}$ and $2.5 \mathrm{~mL}$ potassium ferricyanide $(1 \% \mathrm{w} / \mathrm{v})$. The mixture was then incubated at $50{ }^{\circ} \mathrm{C}$ for $20 \mathrm{~min}$, and $2.5 \mathrm{~mL}$ of trichloroacetic acid $(10 \% \mathrm{w} / \mathrm{v})$ was added. The mixture was centrifuged at $3000 \mathrm{rpm}$ for $10 \mathrm{~min} .2 .5 \mathrm{~mL}$ of the supernatant was mixed with an equal volume of distilled water and $0.5 \mathrm{~mL}$ of $\mathrm{FeCl}_{3}(0.1 \% \mathrm{w} / \mathrm{v})$ and the absorbance was measured at $700 \mathrm{~nm}$. Vitamin C and Rutin were used as positive controls.

\section{ABTS cation free radical-scavenging activity}

For ABTS (2,2'-azino-bis 3-ethylbenzothiazoline-6-sulphonic acid) assay, the procedure followed was the method of Zheleva-Dimitrova et al. (2010) and Roberta et al. (1999) with some modifications. ABTS was dissolved in water to make a concentration of $7 \mathrm{mmol} / \mathrm{L}$. $\mathrm{ABTS}^{+}$was produced by reacting the ABTS stock solution with $2.45 \mathrm{mmol} / \mathrm{L}$ potassium persulfate (final concentration) and the mixture was left in the dark at room temperature for $12-16 \mathrm{~h}$ before use. The $\mathrm{ABTS}^{+}$stock solution was diluted with $80 \%$ methanol to an absorbance of $0.70 \pm 0.02$ at $734 \mathrm{~nm} .4 .85 \mathrm{~mL}$ of diluted ABTS ${ }^{+}$was added to $0.15 \mathrm{~mL}$ of tenfold diluted samples (final concentrations $0.025-0.5 \mu \mathrm{g} / \mathrm{mL}$ of each extract were added, at an equal volume of dry material). The absorbance reading was taken at 6 min after the initial mixing. Gallic acid and BHT were used as positive controls. The activities of the samples were evaluated by comparison with a control (containing $4.85 \mathrm{~mL}$ of ABTS solution and $0.15 \mathrm{~mL}$ of $45 \%$ methanol). ABTS ${ }^{+}$scavenging activity was calculated by the following formula:

$$
\mathrm{ABTS}^{+} \text {scavenging activity }(\%)=[(A c-A s) / A c] \times 100
$$

where $A_{\mathrm{C}}$ is the absorbance value of the control and $A_{\mathrm{S}}$ is the absorbance value of the added samples test solution.

\section{GC-MS analysis}

Five hundred grams (500 g) of the plant sample was distilled using distilled water in an allglass Clevenger apparatus in accordance with British Pharmacopoeia (1980). Heat was supplied to the heating mantle $\left(50{ }^{\circ} \mathrm{C}\right)$ and the essential oils were extracted with $3 \mathrm{~L}$ of distilled water for $3 \mathrm{~h}$. The oil collected was analysed using gas chromatograph-mass spectrometry (GC-MS). The GC-MS was carried out using Agilent 7890B GC system coupled to an Agilent 5977A MSD with a Zebron-5MS column (ZB-5MS $30 \mathrm{~m} \times 0.25 \mathrm{~mm} \times 0.25 \mu \mathrm{m}$ ) (5\%-phenylmethylpolysiloxane). GC grade helium was used as a carrier gas at a flow rate of $2 \mathrm{~mL} / \mathrm{min}$ and splitless $1 \mu \mathrm{L}$ auto-injections were used. The injection temperature was $250{ }^{\circ} \mathrm{C}$ and source temperature was $250{ }^{\circ} \mathrm{C}$. Oven temperature was $70{ }^{\circ} \mathrm{C}$, ramp $15{ }^{\circ} \mathrm{C} /$ min to $120^{\circ} \mathrm{C}$, ramp at $10{ }^{\circ} \mathrm{C} / \mathrm{min}$ to $180{ }^{\circ} \mathrm{C}$ then ramp at $20{ }^{\circ} \mathrm{C} / \mathrm{min}$ to $270{ }^{\circ} \mathrm{C}$ and hold for $3 \mathrm{~min}$. Data was gathered with Chem station. The oil components were identified by matching their mass spectra and retention indices with those of the Wiley 275 library 
(Wiley, New York) in the computer library and literature (Siegler 1998). The yield of the oil was calculated per gram of the plant material, while the percentage composition was calculated from summation of the peak areas of the total oil composition.

\section{Statistical analysis}

The zones of inhibitions induced by the plant extract against the tested microbes were given as mean \pm standard deviation of 3 replicates. Experimental results were analyzed by SPSS version 16.0 (SPSS Inc. Chicago, IL). Differences between means were determined using one-way ANOVA and least significant difference test. The level of statistical significance was set at $P \leq 0.05$.

\section{Results}

\section{Antimicrobial activity}

The extraction yield was $9.3 \%$. The results of the agar well diffusion assay and the MICs of the acetone extract of E. golondrina are summarised in the Table 1 and Fig. 1 below. The highest antibacterial activity with inhibition zone diameter of $20 \pm 1.1 \mathrm{~mm}$, MIC value of $0.01 \mathrm{mg} / \mathrm{mL}$ was observed against $B$. cereus, followed by $S$. aureus with inhibition zone diameter of $17 \pm 1.6 \mathrm{~mm}$, MIC value of $2.5 \mathrm{mg} / \mathrm{mL}$, which was significantly lower $(\mathrm{P}<0.05)$ than the positive control. None of the fungi was inhibited by the acetone extract of E. golondrina except $C$. albicans wherein the zone of inhibition $(21 \pm 2.1 \mathrm{~mm})$ was not significantly different from that of the positive control.

\section{Results of antioxidant assays}

DPPH radical-scavenging activity

The results of the DPPH assay showed that the scavenging activity of Vitamin C and Rutin were higher than E. golondrina at all concentrations (Fig. 2). However, the DPPH scavenging activity of E. golondrina increased with increasing concentration.

Table 1 Inhibition of microbial growth by acetone extract of Euphorbia golondrina L.C. Wheeler

\begin{tabular}{|c|c|c|c|c|}
\hline \multirow[t]{2}{*}{ Microorganism } & \multicolumn{2}{|c|}{ Zone of inhibition $(\mathrm{mm})$} & \multicolumn{2}{|c|}{$\begin{array}{l}\text { Minimum inhibition concentra- } \\
\text { tion }(\mathrm{mg} / \mathrm{mL})\end{array}$} \\
\hline & Extract & Positive control & Extract & Positive control \\
\hline \multicolumn{5}{|l|}{ Bacteria } \\
\hline Escherichia coli & $15 \pm 1.1$ & $30 \pm 0.1$ & 2.5 & $<0.01$ \\
\hline Enterococcus faecalis & $15 \pm 1.6$ & $31 \pm 1.1$ & 2.5 & $<0.01$ \\
\hline Staphylococcus aureus & $17 \pm 1.6$ & $32 \pm 3.1$ & 2.5 & $<0.01$ \\
\hline Bacillus cereus & $20 \pm 1.1$ & $35 \pm 0.1$ & 0.01 & $<0.01$ \\
\hline \multicolumn{5}{|l|}{ Fungi } \\
\hline Penicillium chrysogenum & $\mathrm{Na}$ & $29 \pm 4.1$ & $\mathrm{Na}$ & $<0.01$ \\
\hline Aspergillus fumigatus & $\mathrm{Na}$ & $28 \pm 2.1$ & $\mathrm{Na}$ & $<0.01$ \\
\hline Aspergillus niger & $\mathrm{Na}$ & $26 \pm 0.8$ & & $<0.01$ \\
\hline Candida albicans & $21 \pm 2.1^{*}$ & $22 \pm 0.8$ & 0.01 & $<0.01$ \\
\hline
\end{tabular}

Values are mean \pm SD of triplicates experiments, Na not active

* Not significantly different from positive control $(P<0.05)$, positive control: Amphotericin $B$ for fungi and amoxicillin for bacteria 


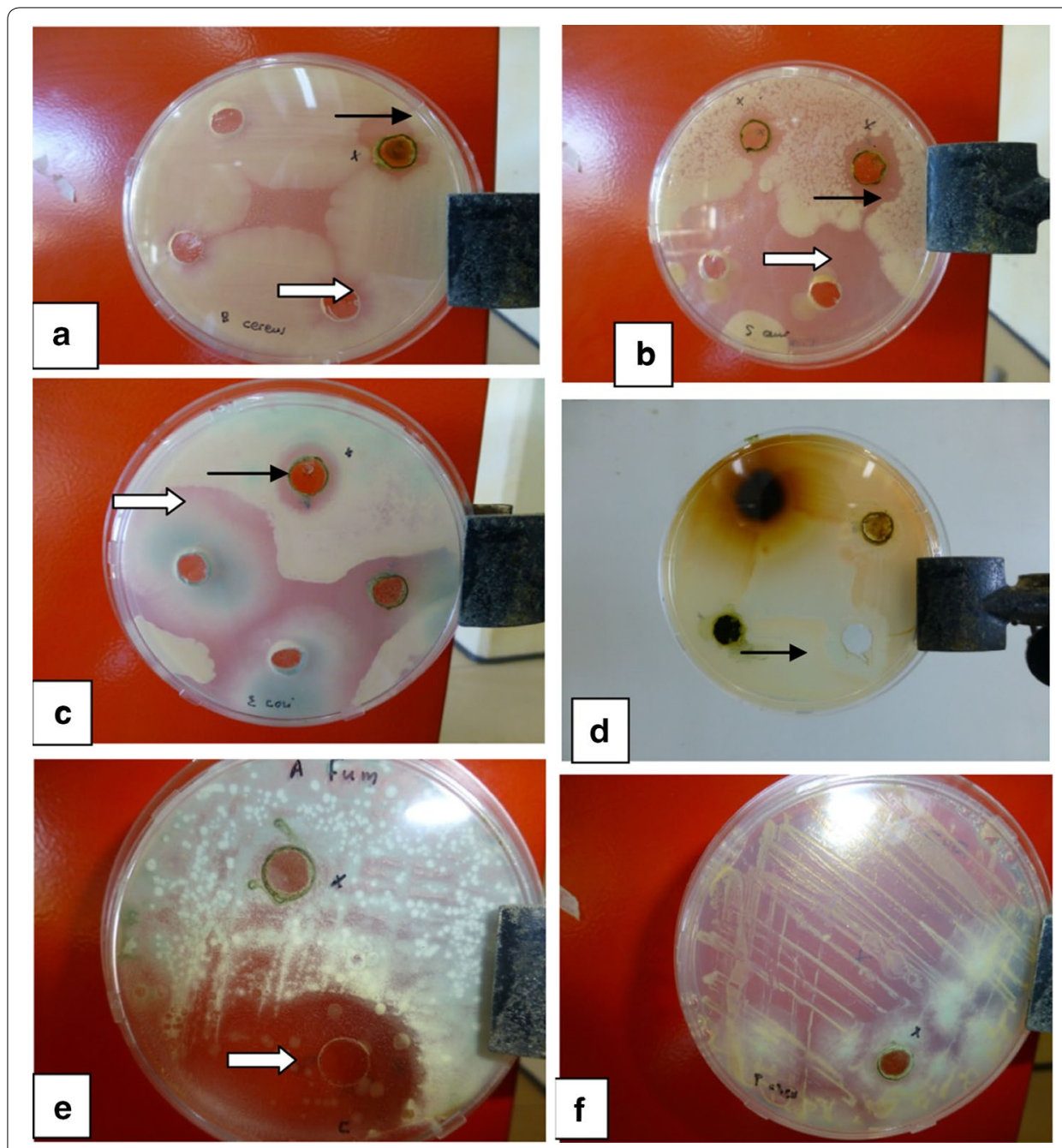

Fig. 1 Susceptibility/tolerance of selected bacteria (a B. cereus; b S. aureus; $\mathbf{c} E$. coli) and fungi (d C. albicans; e Aspergillus fumigates; $\mathbf{f}$ P. chrysogenum) to the acetone extract of Euphorbia golondrina L.C. Wheeler. Black arrow indicates zone of inhibition by extract, white arrow indicates zone of inhibition by positive control

\section{Nitric oxide scavenging activity}

The nitric oxide (NO) scavenging activity of E. golondrina was not dose-dependent, but higher than those of both Rutin and Vitamin C (Fig. 3).

\section{Reducing power assay}

The dose-response curve for the reducing powers of the acetone extract of E. golondrina (as indicated by the absorbance at $700 \mathrm{~nm}$ ) is shown in Fig. 4. Increased absorbance indicates increased reducing power. The reducing power of the acetone extract of E. golondrina was lower than those of both controls.

\section{ABTS scavenging activity}

Scavenging activity was expressed as percentage of inhibition of $\mathrm{ABTS}^{+}$free radical (Fig. 5). The ABTS scavenging activity of E. golondrina was higher than that of gallic acid and $\mathrm{BHT}$ at concentrations greater than 0.1 and $0.2 \mathrm{mg} / \mathrm{mL}$ respectively. 


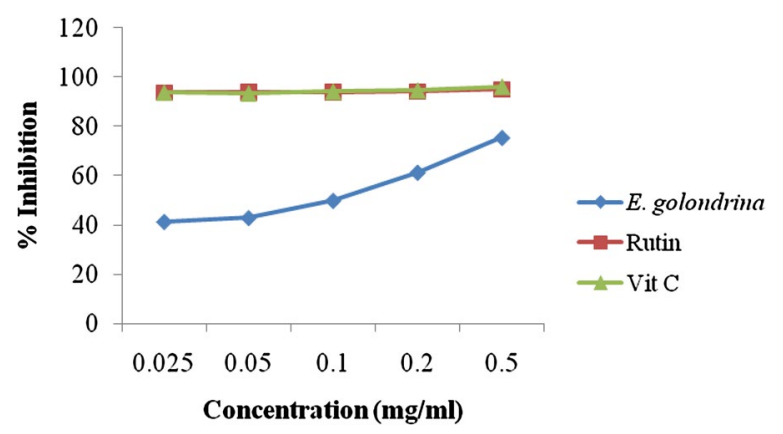

Fig. 2 DPPH scavenging activity of the acetone extract of Euphorbia golondrina L.C. Wheeler

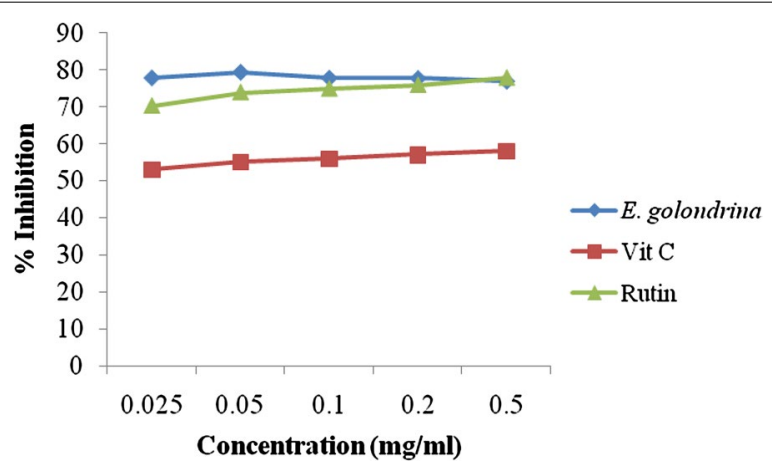

Fig. 3 Nitric oxide scavenging activity of the acetone extract of Euphorbia golondrina L.C. Wheeler

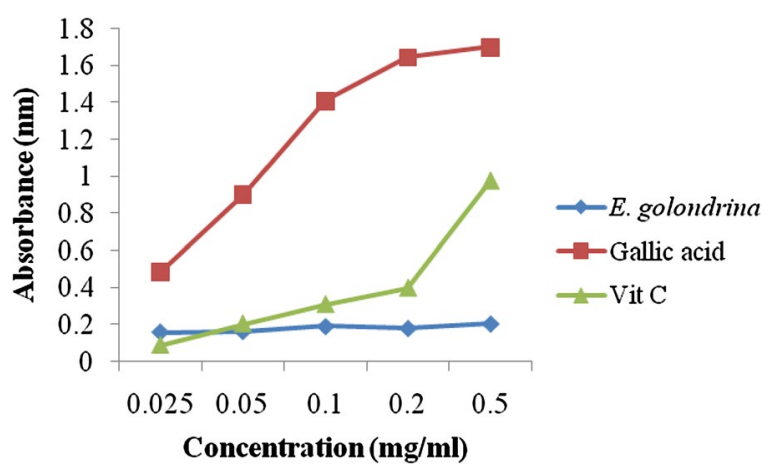

Fig. 4 Reducing power of the acetone extract of Euphorbia golondrina L.C. Wheeler

\section{Result of the GC-MS analysis of E. golondrina}

The characteristics of the phytochemicals identified, including the retention time (RT), relative peak area percentage (peak area relative to the total peak area) and chemical structures of phytoconstituents of the E. golondrina extract are summarized in Table 2. The various classes of phytochemicals in the E. golondrina plant provided the antioxidant and antimicrobial potency of the plant. Thirty compounds were identified from the steam distilled volatile of E. golondrina with caryophyllene oxide (14.16 \%), camphor $(9.41 \%)$ and phytol (5.75 \%) being the most abundant. These were followed by 


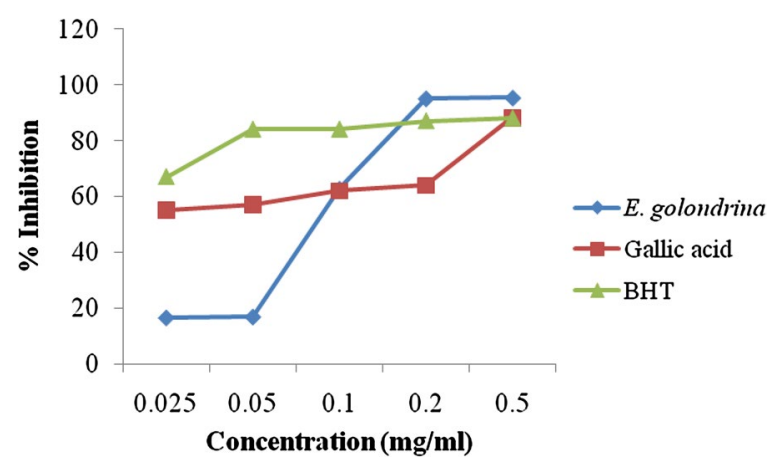

Fig. 5 ABTS scavenging activity of the acetone extract of Euphorbia golondrina L.C. Wheeler

2,6-diisopropylnaphthalene (4.77\%), octasiloxane (4.38\%), furan (3.04\%), nanonal (3.32\%), eucalyptol (2.92\%) and 3,4-dimethylanisole (2.30\%).

\section{Discussion}

Euphorbia golondrina is used to treat enterocolitis, vaginitis and conjunctivitis by the Mexicans and the Mundani people of the mount Bambouto Caldera, SouthWestern Cameroon (Ndam et al. 2015a, b; Rodriguez 2013; Aleksandroff 2011). Vaginitis is responsible for an estimated 10 million physician visits by women annually and invasion of the epithelial cells of female genitals by $C$. albicans causes itching and inflammation (Gibbs et al. 2009). Treatment by azoles such as fluconazole has not been effective in eradicating these infections. Hence, many women use complementary treatments (Imhof et al. 2005) with alternative medicine partly because of their fewer side effects and lower cost. The fact that the acetone extract of E. golondrina was fungicidal against C. albicans, is a partial justification of the ethnopharmacological use of the plant against vaginitis and also highlights the possibility of discovering new antifungal compounds with novel mechanisms of action from the plant. However, the inability of the acetone extract of E. golondrina to inhibit the growth of P. chrysogenum, A. fumigates, and A. niger despite its extensive use in traditional medicine is worth investigating. We hypothesise that acetone may not have extracted some of the antifungal compounds present in the plant or the medicinal compounds in the plant may have alternative modes of therapeutic action that may boost the immune system of the body.

Enterocolitis is an inflammation of the digestive tract that results in enteritis of the small intestine and colitis of the colon. Many bacteria as well as fungi and viruses are responsible for the development of enterocolitis in humans but the most common etiologic agents of the disease are: Salmonella, Shigella, E. coli, and S. aureus. Although most E. coli are commensals found in the gut of humans, some pathogenic strains are distinguished from normal flora by the possession of virulence factors such as exotoxins. The most common symptoms of enterocolitis are frequent diarrhoea, fever, vomiting and abdominal pain. S. aureus is the causative agent of acute bacterial conjunctivitis in humans, where as Streptococcus pneumoniae and Haemophilus influenzae are causative agents of conjunctivitis in children (Buznach et al. 2005). In the current study, the acetone extract of $E$. golondrina displayed a moderate antibacterial activity especially against E. coli, strong antibacterial activity against $S$. aureus and B. cereus, indicating 
Table 2 Phytochemicals in Euphorbia golondrina L.C. Wheeler identified by GC-MS

\begin{tabular}{|c|c|c|c|c|}
\hline Compound & Class & $\begin{array}{l}\text { Retension } \\
\text { time }\end{array}$ & \begin{tabular}{|l|}
$\begin{array}{l}\text { Area } \\
(\%)\end{array}$ \\
\end{tabular} & $\begin{array}{l}\text { Structure, molecular formula and } \\
\text { weight }\end{array}$ \\
\hline Benzo[h]quinoline & Alkaloid & 10.668 & 1.76 & $\mathrm{C}_{13} \mathrm{H}_{9} \mathrm{~N}(\mathrm{M}=179.20)$ \\
\hline Indole & Alkaloid & 7.582 & 1.18 & $\mathrm{C}_{8} \mathrm{H}_{7} \mathrm{~N}(\mathrm{M}=117.15)$ \\
\hline Camphor & Monoterpene & 9.995 & 9.41 & $\mathrm{C}_{10} \mathrm{H}_{16} \mathrm{O}(\mathrm{M}=152.12)$ \\
\hline Eucalyptol & Monoterpene & 6.862 & 2.92 & $\mathrm{C}_{10} \mathrm{H}_{18} \mathrm{O}(\mathrm{M}=154.14)$ \\
\hline Caryophyllene & Sesquiterpene & 7.098 & 1.59 & $20.39)$ \\
\hline
\end{tabular}

that the plant could be a good source of antibacterial and confirming its ethnomedicinal usage in the study area against enterocolitis and conjunctivitis. Although there have been no previous reports on the antibacterial activity of E. golondrina in scientific literature, other Euphorbia species have been noted for their antibacterial activity. The ethyl acetate fraction of the methanolic extract of Euphorbia pulcherrima was reported to contain phytochemicals which showed remarkable activities against E. coli, S. aureus, Salmonella typhi, and Pseudomonas aeruginosa (Sharif et al. 2011). Methanolic extracts and latex of some species of Euphorbia are known to inhibit the growth of $S$. aureus, Bacillus megaterium, Proteus vulgaris, Klebsiella pneumonia, E. coli, P. aeruginosa and C. albicans (Kirbag et al. 2013).

In the Mexican ethnopharmacopoeia, E. golondrina is used to treat rheumatism while it is applied to relieve painful swellings by the Mundani people of the mount Bambouto Caldera, SouthWestern Cameroon (Ndam et al. 2015a, b; Rodriguez 2013; Aleksandroff 
Table 2 continued

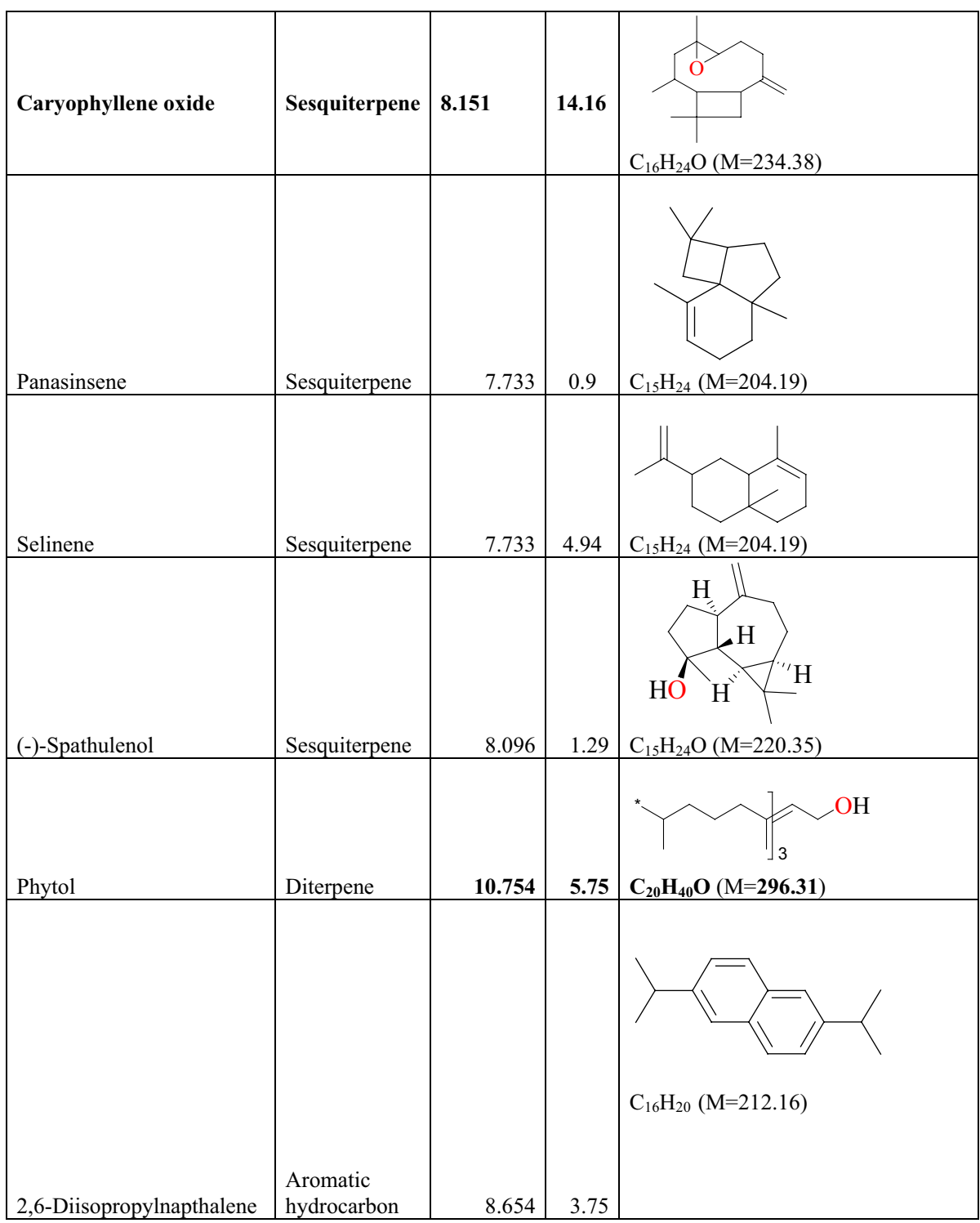

2011). Rheumatism is an inflammatory autoimmune disease marked by polyarthritis that is erosive, progressive and chronic. The use of E. golondrina for the traditional management of rheumatism in Cameroon suggests that antioxidants in the plant may have an important role to play as they lower the oxidative stress and the resultant inflammatory damage. In the present study, antioxidant evaluation of the acetone extract of $E$. golondrina was conducted using DPPH, reducing power, nitric oxide and ABTS radical scavenging assays. Potent antioxidant activity was observed during the nitric oxide and ABTS scavenging assays. The ABTS radical $\left(\mathrm{ABTS}^{+}\right)$scavenging abilities of the acetone extract of E. golondrina were more effective than the standards; gallic acid and BHT at higher concentrations of 0.1 and $0.2 \mathrm{mg} / \mathrm{mL}$, respectively. It was assumed that antioxidants in E. golondrina simply reduce the radical back to the parent substrate, ABTS. The radical scavenging activity of the crude extract of Euphorbia cortinifolia against 
Table 2 continued

\begin{tabular}{|c|c|c|c|c|}
\hline 2(1H)-Naphthalene & $\begin{array}{l}\text { Aromatic } \\
\text { hydrocarbon }\end{array}$ & 8.834 & 0.9 & $\mathrm{C}_{10} \mathrm{H}_{10}(\mathrm{M}=130.19)$ \\
\hline 1,3-Diisopropylnapthalene & $\begin{array}{l}\text { Aromatic } \\
\text { hydrocarbon }\end{array}$ & 8.895 & 2.39 & $\mathrm{C}_{16} \mathrm{H}_{20}(\mathrm{M}=$ \\
\hline 1,4-Diisopropylnapthalene & $\begin{array}{l}\text { Aromatic } \\
\text { hydrocarbon }\end{array}$ & 8.919 & 4.31 & $\mathrm{C}_{16} \mathrm{H}_{20}(\mathrm{M}=2$ \\
\hline Furan & $\begin{array}{l}\text { Aromatic } \\
\text { compoud }\end{array}$ & 3.765 & 3.04 & $\mathrm{C}_{4} \mathrm{H}_{4} \mathrm{O}(\mathrm{M}=68.08)$ \\
\hline Trans-2-(2-pentenyl)furan & $\begin{array}{l}\text { Aromatic } \\
\text { compoud }\end{array}$ & 3.845 & 0.9 & $\mathrm{C}_{9} \mathrm{H}_{12} \mathrm{O}(\mathrm{M}=136.19)$ \\
\hline Dibutylphthalate & Aromatic ester & 10.075 & 2.75 & $\mathrm{C}_{16} \mathrm{H}_{20} \mathrm{O}_{4}(\mathrm{M}=27$ \\
\hline Nonanal & Aldehyde & 4.657 & 3.32 & $\mathrm{C}_{9} \mathrm{H}_{18} \mathrm{O} \quad(\mathrm{M}=142.2$ \\
\hline
\end{tabular}

ABTS showed $\mathrm{IC}_{50}$ of $95.61 \pm 1.5 \mu \mathrm{g} / \mathrm{mL}$, compared to the standard, BHT with $\mathrm{IC}_{50}$ of $90.91 \pm 1.4 \mu \mathrm{g} / \mathrm{mL}$ (Hosain et al. 2014). Whilst there exist a dearth of scientific literature on the ABTS scavenging activity of Euphorbia species, this study present the first report on the ABTS scavenging activity of E. golondrina.

In the present study, the acetone extract of E. golondrina at different concentrations was assessed for nitrite free radical scavenging activity in an in vitro model. The nitric oxide scavenging activity of the acetone extract of E. golondrina was higher than that of both vitamin $\mathrm{C}$ and Rutin. The activity of the acetone extract could be attributed to phyto-components such as phenolic compounds. Polyphenols are major antioxidant components present in most plant extracts (Ebrahimzadeh et al. 2010). The acetone extract is thought to contain polyphenols since acetone effectively penetrates cellular membranes of plants resulting in the extraction of polyphenols (Sumazian et al. 2010). 
Table 2 continued

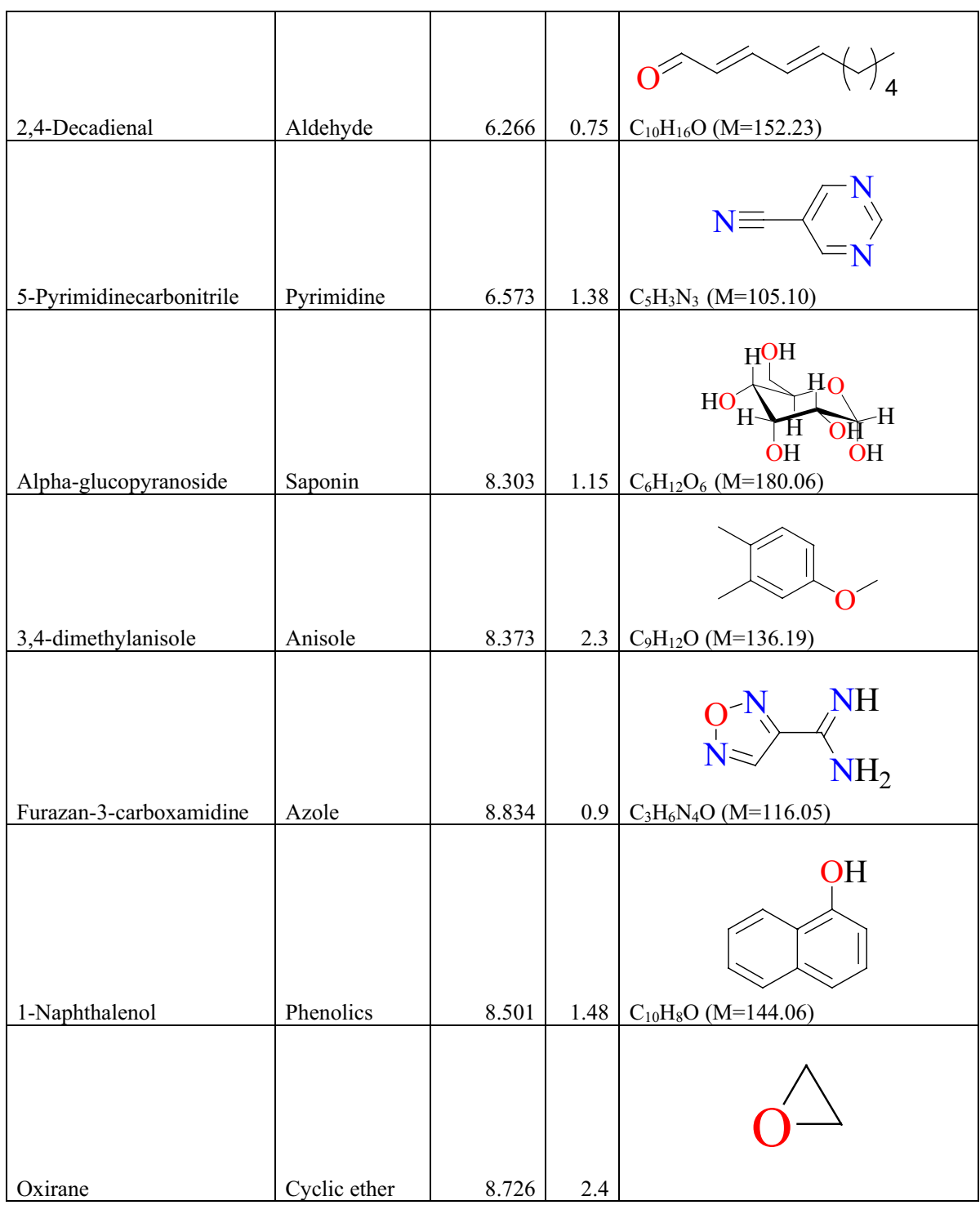

Other studies have shown that the genus Euphorbia is extremely rich in polyphenolics; 9 antioxidant polyphenols: scopoletin, scoparone, isoscopoletin, quercetin, isorhamnetin, pinocembrin, kaempferol, luteolin, and gallic acid were preliminary identified from Euphorbia hirta (Wu et al. 2012). Ferulic acid is a phenolic compound that was identified from Euphorbia tirucalli (De Araújo 2014). Boudiar et al. (2010) identified six known flavonoids namely, kaempferol, kaempferol 3-O-glucoside, kaempferol 3-rutinoside, quercetin, quercetin 3-O-glucoside, and rutin from the aerial parts of Euphorbia guyoniana. This suggests that E. golondrina might contain compounds that scavenge and this may account for the regulation of pathological conditions induced by nitric oxide and its oxidation product, peroxynitrite. Nitric oxide has been reported to be scavenged by flavonoids and saponins (Patel et al. 2010). Hence, the presence of phenolics and saponins compounds such as 1-naphthalenol and alpha-glucopyranoside could partially explain 
Table 2 continued

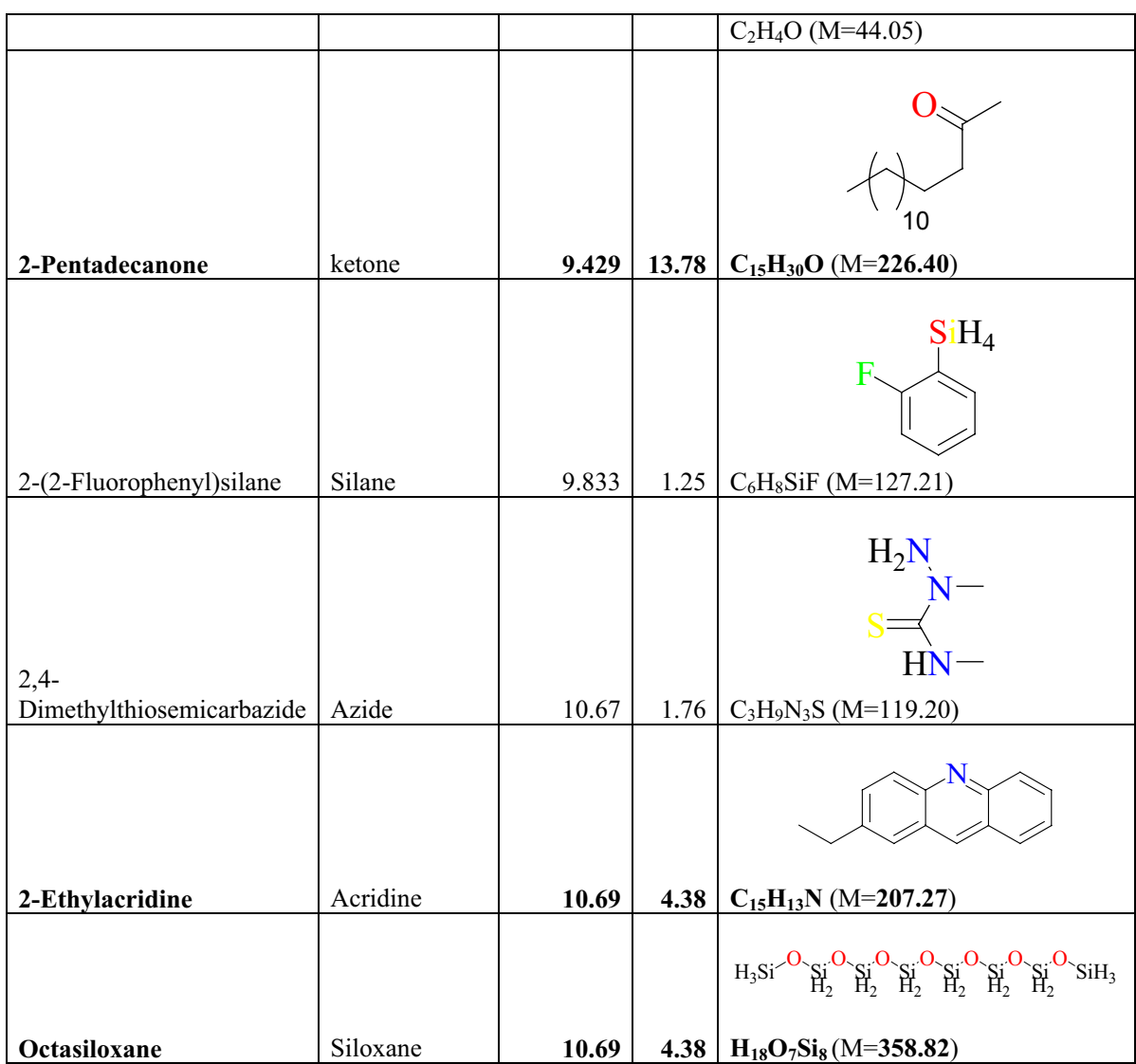

why E. golondrina is more potent at quenching the nitric oxide radical. Since chronic exposure to nitric oxide radical is associated with inflammatory diseases such as arthritis, the scavenging of E. golondrina acetone extract could partially justify the folkloric use of the plant in the treatment of rheumatism.

The GC-MS analysis of E. golondrina reveals an extremely impressive array of compounds such as caryophyllene oxide, eucalyptol, dibutylthalate, acetanilide, phenylacetamide, phytol, camphor, etc. Caryophyllene, selinene, paninsene and spathulenol are the sesquiterpenes identified in E. golondrina. Terpenoids are active against bacteria and fungi (Salari et al. 2006; Cowan 1999). Eucalyptol showed antibacterial activity against some pathogenic bacteria in the respiratory tract (Salari et al. 2006) and because of its antimicrobial properties, it is also used in dental care and soaps. Dibutylphthalate was the only phthalate that was identified from E. golondrina. Although few reports are available for the antibacterial potential of phthalate derivatives from plants, bis (2-ethylhexyl) phthalate extracted from Streptomyces bangladheshiensis has been reported to show antibacterial activity against Gram-positive bacteria while the anti-inflammatory activity of di (2-ethylhexyl) phthalate from Alchornea sp. was reported (Camila et al. 2013). Phenylacetamide (acetanilide), although no longer used as a drug, it was the first analgesic and antipyretic aniline and the success of its metabolite is well documented (Bertolini et al. 2006). The in vitro antioxidant effect of phytol including its capacity to 
remove hydroxyl radicals and nitric oxide has also been reported (Camila et al. 2013). Camphor is commonly used topically to relieve muscular pains especially in osteoarthritis and also for the treatment of fungal infections of the toe nail (Farhat et al. 2001). In the current study, structural characterisation of the purported compounds was limited to comparative MS spectral analysis of the steam distilled volatiles of E. golondrina. Further, structural characterisation based on ${ }^{1} \mathrm{H}$ and ${ }^{13} \mathrm{C} N \mathrm{NM}$ is required to demonstrate structural integrity including correct stereochemistry which may be present in terpene compounds.

\section{Conclusion}

This study has demonstrated the activity of the acetone extract of E. golondrina against microorganisms of human pathogenic interest which confirms the ethnopharmacological uses of the plant. However, it was not active against Penicilium and Aspergilus which are important human pathogens and storage pathogens of plant and plant products. The extract also showed significant antioxidant properties, indicative of its potential as a source. The plethora of compounds elucidated by the GC-MS needs further investigation for possible exploitation for pharmaceutical uses.

\section{Authors' contributions}

LMN is the main author, participated in designing the research, data collection, analysis and drafted this manuscript. AMM, AST, AGNF and YF are supervisors of this research and participated in designing the research, data collection and reviewing manuscript. NAT participated in data collection and analysis. All authors read and approved the final manuscript.

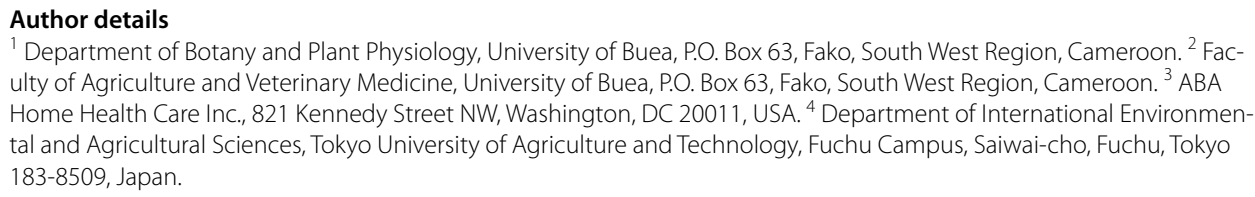

\section{Acknowledgements}

This study was financially supported by Community Career Development Foundation Cameroon (COCADEF GRANT No. 1015). The Department of Botany of the University of Fort Hares, South Africa is credited for the laboratory analysis aspect of this work. We are grateful to Mr. Babiaka Smith Borakaeyabe of the Department of Chemistry, University of Buea, Cameroon, for generating the 2D structures of the compounds.

\section{Competing interests}

The authors declare that they have no competing interests.

Received: 30 September 2015 Accepted: 23 February 2016

Published online: 02 March 2016

\section{References}

Aleksandroff S (2011) Plants in the Mayan culture, 1st edn. Imago, Playal de Carmen

Balandrin MF, Kinghorn AD and Farnsworth NR (1993) Plant-derived natural products in drug discovery and development: an overview human medicinal agents from plants. In: Kinghorn AD, Balandrin MF (eds) American chemical society symposium, vol 534, Washington, DC, pp 2-12

Bertolini A, Ferrari A, Ottani A, Guerzoni S, Tacchi R, Leone S (2006) Paracetamol: new vistas of an old drug. CNS Drug Rev 12(3-4):250-275

Boudiar T, Hichem L, Khalfallah A, Kabouche A, Kabouche Z, Brouard I, Bermejo J, Bruneau C (2010) A new alkaloid and flavonoids from the aerial parts of Euphorbia guyoniana. Nat Prod Commun 5(1):35-37

Buffet-Bataillon S, Tattevin P, Bonnaure-Mallet M, Jolivet-Gougeon A (2012) Emergence of resistance to antibacterial agents: the role of quaternary ammonium compounds - a critical review. Int J Antimicrob Agents 39:381-389

Buznach N, Dagan R, Greenberg D (2005) Clinical and bacterial characteristics of acute bacterial conjunctivitis in children in the antibiotic resistance era. Pediatr Infect Dis J 24(9):823-828

Camila CDMPS, Salvadori MS, Mota VG, Costa LM, Antonia ACDA, Guilherme ALDO, Jéssica PC, Damião PDS, Rivelilson MDF, Reinaldo NDA (2013) Antinociceptive and antioxidant activities of phytol in vivo and in vitro models. J Neurosci 2013(2013), Article ID 949452

Cowan MM (1999) Plant products as antimicrobial agents. Clin Microbiol Rev 12:564-582 
Davies J, Davies D (2010) Origins and evolution of antibiotic resistance. Microbiol Mol Biol Rev 74:417-433

De Araújo KM (2014) Identification of phenolic compounds and evaluation of antioxidant and antimicrobial properties of Euphorbia Tirucalli L. Antioxidants 3(1):159-175

Duracková Z (2010) Some current insights into oxidative stress. Physiol Res 59:459-469

Ebrahimzadeh A, Nabavi SM, Nabavi SF, Bahramian F, Bekhradnia AR (2010) Antioxidant and free radical scavenging activity of H. officinalis L. var. angustifolius, V. odorata, B. hyrcana and C. speciosum. Pak J Pharm Sci 23(1):29-34

Fabricant DS, Farnsworth NR (2010) The value of plants used in traditional medicine for drug discovery. Environ Health Perspect 109(1):69-75

Farhat GN, Affara NI, Gali-Muhtasib HU (2001) Seasonal changes in the composition of the essential oil extract of East Mediterranean sage (Salvia libanotica) and its toxicity in mice. Toxicon 39(10):1601-1605

Gibbs RS, Danforth DN, Karlan BY, Haney AF (2009). Danforth's obstetrics and gynecology (trans: Valdan M, Bozari B, Faghani Jadidi N). Razzagian Tehran: Arjmand: Nasle Farda (in Persian)

Hosain H, Shaikh ER, Proity NA, Tanzir AK (2014) Determination of antioxidant activity and hplc profile of Euphorbia cotinifolia. World J Pharm Res 3(7):93-104

Imhof M, Lipovac M, Kurz C, Barta J, Verhoeven HC, Huber JC (2005) Propolis solution for the treatment of chronic vaginitis. Int J Gynaecol Obstet 89(2):127-132

Kirbag S, Erecevit P, Zengin F, Guvenc AN (2013) Atimicrobial activities of some Euphorbia species. Afr J Tradit Complement Altern Med 10(5):305-309

Koduru S, Grierson DS, Afolayan AJ (2006) Antimicrobial activity of Solanum aculeastrum. Pharm Biol 44:283-286

Lu Y, Zhao YP, Wang ZC, Chen SY, Fu CX (2007) Composition and antimicrobial activity of the essential oil of Actinidia macrosperma from China. Nat Prod Res 21(3):227-233

Mbwambo ZH, Moshi MJ, Masimba PJ, Kapingu MC, Nondo RS (2007) Antimicrobial activity and brine shrimp toxicity of extracts of Terminalia brownie roots and stem. BMC Complement Altern Med 7(9):1-5

N'guessan JD, Dinzedi MR, Guessennd N, Coulibaly A, Dosso M, Djaman AJ, Guede-Guina F (2007) Antibacterial activity of the aqueous extract of Thonningia sanguinea against extended-spectrum- $\beta$-lactamases (ESBL) producing Escherichia coli and Klebsiella pneumoniae strains. Trop J Pharm Res 6(3):779-783

Ndam LM, Mih AM, Fongod AGN, Tening AS, Tonjock RK, Enang JE, Fujii Y (2014) Phytochemical screening of the bioactive compounds in twenty (20) Cameroonian medicinal plants. Int J Curr Microbiol App Sci 3(12):768-778

Ndam LM, Mih AM, Fongod AGN, Tening AS, Temenu NA, Fujii Y (2015a) First record of Euphorbia golondrina L. C. Wheeler (Euphorbiaceae) in Cameroon. J Biodiversity Environ Sci 6(4):428-434

Ndam LM, Mih AM, Fongod AGN, Tening AS, Temenu NA, Fujii Y (2015b) Foliar micromorphology of Euphorbia golondrina L. C. Wheeler (Euphorbiaceae) from Cameroon. Int J Curr Res 7(7):18261-18267

Newman DJ, Cragg GM (2007) Natural products as sources of new drugs over the last 25 years. J Nat Prod 70(3):461-477

Nonita PP, Mylene MU (2010) Antioxidant and cytotoxic activities and phytochemical screening of four Philippine medicinal plants. J Med. Plants Res 4:407-414

Otang WM, Grierson DS, Ndip RN (2012) Antifungal activity of Arctotis arctotoides (L.f.) O. Hoffm. and Gasteria bicolor Haw. against opportunistic fungi associated with human immunodeficiency virus/acquired immunodeficiency syndrome. Pharmacogn Mag 8(30) (ISSN: 0973-1296)

Patel VR, Patel PR, Kaja SS (2010) Antioxidant activity of some selected medicinal plants in western region of India. Adv Biol Res 4(1):23-26

Reuter S, Gupta SC, Chaturvedi MM, Aggarwal BB (2010) Oxidative stress, inflammation, and cancer: how are they linked? Free Radic Biol Med 49(11):1603-1616

Roberta R, Pellegrini N, Proteggente A, Pannala A, Yang M, Rice-Evans C (1999) Antioxidant activity applying an improved ABTS radical cation decolorization assay. Free Radic Biol Med 26:1231-1237

Rodriguez BGB (2013) Etnobotanica des Tres Municipos Del Norte del Estado Nuevo Leon, Mexico. Tesis Maestria Forestia en Ciencias Forestales. Universidad Avatonoma, Nuevo Leon, Mexico, 75 pp

Salari MH, Amine G, Shirazi MH, Hafezi R, Mohammadypour M (2006) Antibacterial effects of eucalyptus globulus leaf extract on pathogenic bacteria isolated from specimens of patients with respiratory tract disorders. Clin Microbiol Infect 12(2):194-196

Sharif HB, Mukhtar MD, Mustapha Y, Lawal AO, Ekundayo FO, Adeboye CA, Ekundayo EA (2011) Antimicrobial activities and phytochemical screening of pignut (Jatrophas curcas Linn.) on some pathogenic bacteria. J Med Plants Res 5(7):1261-1264

Siegler DS (1998) Plant secondary metabolism. Kluwer, Dordretch

Sumazian Y, Syahida A, Hakiman M, Maziah M (2010) Antioxidant activities, flavonoids, ascorbic acid and phenolic contents of Malaysian vegetables. J Med Plant Res 4(10):881-890

Verpoorte R (2000) Pharmacognosy in the new millennium: leadfinding and biotechnology. J Pharm Pharmacol 52(3):253-262

Wu Y, Qu W, Geng D, Liang JY, Luo YL (2012) Phenols and flavonoids from the aerial part of Euphorbia hirta. Chin J Nat Med 10(1):40-42

Zheleva-Dimitrova DZ, Nedialkov P, Kitanov G (2010) Radical scavenging and antioxidant activities of methanolic extracts from Hypericum species growing in Bulgaria. Pharmacogn Mag 6:74-78 